\title{
Agitated shoot cultures of Aronia arbutifolia and Aronia $\times$ prunifolia: biotechnological studies on the accumulation of phenolic compounds and biotransformation capability
}

\author{
Agnieszka Szopa $^{1}$ (D) $\cdot$ Paweł Kubica $^{1} \cdot$ Halina Ekiert $^{1}$
}

Received: 30 October 2017 / Accepted: 21 May 2018 / Published online: 29 May 2018

(c) The Author(s) 2018

\begin{abstract}
In methanolic extracts of the biomass from agitated cultures of Aronia arbutifolia and Aronia $\times$ prunifolia grown on four variants of the Murashige and Skoog (MS) medium, with different concentrations of plant growth regulators (PGRs): BA and NAA $(0.5-3.0 \mathrm{mg} / \mathrm{l})$, the quantities of phenolic acids (19 compounds) and flavonoids (11 compounds) were estimated using the LC-DAD method. The amounts of individual metabolites and total contents were dependent on the concentration of PGRs in MS medium variant. The maximum total amounts of phenolic acids and flavonoids reached 360.80 and $65.26 \mathrm{mg} / 100 \mathrm{~g}$ DW, and 659.51 and $78.34 \mathrm{mg} / 100 \mathrm{~g} \mathrm{DW}$ for A. arbutifolia and A. × prunifolia, respectively. The main metabolites in the biomass of both plants were chlorogenic acid, rosmarinic acid and quercitrin (max. 175.94, 147.98 and $41.14 \mathrm{mg} / 100 \mathrm{~g}$ DW, and 260.34, 225.26 and $78.34 \mathrm{mg} / 100 \mathrm{~g}$ DW, respectively). The cells of both plants convert the exogenously supplied hydroquinone into its $\beta$-D-glucoside - arbutin. The maximal total content of the product accumulated in the biomass and media reached 83.55 and $73.62 \mathrm{mg} / \mathrm{g}$ DW. The obtained results demonstrated for the first time a high biosynthetic potential of agitated cultures of both plants.
\end{abstract}

Keywords Flavonoids $\cdot$ Phenolic acids $\cdot$ Arbutin $\cdot$ Hydroquinone $\cdot$ Red Aronia $\cdot$ Purple Aronia

$\begin{array}{ll}\text { Abbreviations } \\ \text { BA } & \text { 6-Benzyladenine } \\ \text { DW } & \begin{array}{l}\text { Dry weight } \\ \text { LC-DAD }\end{array} \\ \begin{array}{l}\text { Liquid chromatography with photodiode array } \\ \text { detection }\end{array} \\ \text { MS } & \begin{array}{l}\text { Murashige and Skoog } \\ \text { NAA }\end{array} \\ \text { 1-Naphthaleneacetic acid } \\ \text { PGR } & \text { Plant growth regulator }\end{array}$

Communicated by Sergio J. Ochatt.

Agnieszka Szopa

a.szopa@uj.edu.pl

Halina Ekiert

mfekiert@cyf-kr.edu.pl

1 Chair and Department of Pharmaceutical Botany, Jagiellonian University, Collegium Medicum, ul. Medyczna 9, 30-688 Kraków, Poland

\section{Introduction}

The groups of plant metabolites that are important in therapy, in the production of healthy food and also in cosmetology include polyphenolic compounds, such as phenolic acids and flavonoids (Hussain et al. 2012). These two groups of compounds have been proven to have valuable antioxidant properties (Krolicka et al. 2008; Procházková et al. 2011; Giri et al. 2012). Rich natural sources of these compounds are still being sought. An interesting proposition is to use, for example, biotechnological solutions by attempting to obtain antioxidants from plant cultures in vitro (Matkowski 2008).

In recent years, many phenolic acids, both derivatives of cinnamic acid and of benzoic acid, and also depsides have been proven to have progressively more biological properties of vital importance in therapy, e.g. immunostimulatory, antiaggregative and anti-cancer (Thurow 2012; Piazzon et al. 2012; Meng et al. 2013; Kakkar and Bais 2014; Döring and Petersen 2014). Flavonoid compounds, despite anti-inflammatory, antiphlogistic and vasoprotective activities, have recently been demonstrated to have neuroprotective and anti-HIV properties and to be valuable in the treatment of 
periprosthetic osteolysis and the prevention of obesity (Arts and Hollman 2005; Pasetto et al. 2014; D'Andrea 2015).

The genus Aronia includes North American species which have been successfully grown in Asia and Europe (Kulling and Rawel 2008). The most well-known and studied species is Aronia melanocarpa (black chokeberry). Information on the chemical composition of A. arbutifolia (red chokeberry) and $A . \times$ prunifolia (purple chokeberry)a hybrid of A. arbutifolia and A. melanocarpa, is modest. Analysis of the fruit extracts has shown them to contain flavonoids and hydroxycinnamic acids, among others (Taheri et al. 2013). Our recent phytochemical studies of extracts from the fruits and leaves collected in two different growing seasons from soil-grown plants, from which cultures were derived in vitro, have demonstrated, among other things, the high amounts of two depsides-chlorogenic acid and neochlorogenic acid (found both in the fruits and leaves), and of selected flavonoid compounds-quercetin, quercitrin and rutoside, and also rosmarinic acid (found in the leaves) (Szopa et al. 2017).

In our previous studies with stationary shoot cultures of A. arbutifolia and A. $\times$ prunifolia, we had proven their ability to accumulate both phenolic acids and flavonoids in notable amounts (Szopa et al. 2018). Encouraged by those results, we had decided to establish agitated cultures of both plants, as a type of cultures more valuable for practical applications, and as a preliminary step for growing cultures in large-scale installations.

The agitated shoot cultures were maintained on four variants of the Murashige and Skoog (MS) medium (Murashige and Skoog 1962), which contained different amounts of plant growth regulators (PGRs): cytokinin (BA) and auxin (NAA), in a concentration range of 0.5 to $3.0 \mathrm{mg} / \mathrm{l}$. Methanolic extracts from the biomass were analyzed with the LC-DAD method for phenolic acids — cinnamic and benzoic acid derivatives (19 compounds), and cinnamic acid as a precursor of one subgroup of phenolic acids, and flavonoid aglycones ( 4 compounds) and glycosides (7 compounds).

The agitated cultures grown on the MS medium containing $2 \mathrm{mg} / \mathrm{l} \mathrm{BA}$ and $2 \mathrm{mg} / \mathrm{l}$ NAA were also used to investigate the ability of the cells of shoots cultured in vitro to perform biotransformation of exogenously delivered hydroquinone into arbutin-its $\beta$-D-glucoside. Arbutin, a phenolic glycoside, occupies an important position in medicine, as a compound effective in the treatment of urinary tract inflammation, and in cosmetology, as a valuable and safe skin bleaching agent. More recent studies have additionally proven the antitussive, antifungal and antioxidant properties of arbutin (Ekiert et al. 2013b; Migas and Krauze-Baranowska 2015).

In our present study the aim was to optimize the process of biotransformation of hydroquinone into arbutin. This consisted in testing different doses of the precursor-hydroquinone $(100-400 \mathrm{mg} / \mathrm{l})$, and different ways of administering it (undivided single dose and divided into 2 and 3 portions). Methanolic extracts from the biomass and lyophilizates of the media were analyzed by LC-DAD to determine the amounts of the product-arbutin.

The choice of the composition of the culture medium was dictated by the desire to compare the biosynthetic potential of the cells in these cultures with the results of earlier studies of agitated cultures of A. melanocarpa. The optimization of the biotransformation of hydroquinone into arbutin in $A$. melanocarpa cultures was performed with agitated microshoots cultivated on the variant of the MS medium containing $2 \mathrm{mg} / \mathrm{l}$ each of BA and NAA (Kwiecień et al. 2013).

The entire study, of both the ability of cells from the agitated cultures of $A$. arbutifolia and A. $\times$ prunifolia to accumulate endogenously phenolic acids and flavonoids, and of an efficient biotransformation of an exogenous precursor-hydroquinone, was aimed at exploring the biosynthetic potential of cells from agitated cultures of the two plants. To date, no research centre has carried out similar studies with agitated cultures of either A. arbutifolia or A. $\times$ prunifolia. Previous biotechnological studies of the two plants by other centres concerned only the development of micropropagation protocols (Brand and Cullina 1992).

\section{Materials and methods}

\section{Basal shoot in vitro cultures}

The shoot in vitro cultures of Aronia arbutifolia (L.) Pers. and Aronia $\times$ prunifolia (Marsh.) Rhed. were initiated as described previously (Szopa et al. 2018). The shoot cultures were maintained on the MS (Murashige and Skoog 1962) medium supplemented with $1.0 \mathrm{mg} / \mathrm{l} \mathrm{BA}$ (6-benzylaminopurine) and $1.0 \mathrm{mg} / \mathrm{l} \mathrm{NAA}$ (1-naphthaleneacetic acid). The MS medium contained $3 \%$ sucrose $(\mathrm{w} / \mathrm{v})$ and was solidified with $0.8 \%$ agar (w/v) (Duchefa Biochemie, Netherlands). The cultures were grown in vessels for plant tissue cultures $(100 \mathrm{ml}$, $66 \mathrm{~mm} \times 59 \mathrm{~mm}$ ), with special Magenta B-caps (SigmaAldrich, USA), in a phytotron at $25 \pm 2{ }^{\circ} \mathrm{C}$ under constant artificial light $\left(16 \mu \mathrm{mol} \times \mathrm{m}^{-2} \times \mathrm{s}^{-1}\right)$ and were transferred onto the same fresh medium every 4 weeks.

\section{Endogenic accumulation of metabolites}

\section{Experimental in vitro cultures}

In order to perform the experiment, the basal cultures of $A$. arbutifolia and $A . \times$ prunifolia (as described above) were used to establish agitated shoot cultures in $300 \mathrm{ml}$ Erlenmeyer flasks. The inoculum consisted of $2 \mathrm{~g}$ of fresh shoots for one flask containing $100 \mathrm{ml}$ of MS liquid medium with $3 \%$ sucrose (w/v) ( $\mathrm{pH}$ 5.7). Four variants of the MS medium 
with different concentrations of BA and NAA: $0.5 \mathrm{mg} / \mathrm{lBA}$ and $2 \mathrm{mg} / \mathrm{l} \mathrm{NAA} ; 2 \mathrm{mg} / \mathrm{l} \mathrm{BA}$ and $2 \mathrm{mg} / \mathrm{l} \mathrm{NAA} ; 2 \mathrm{mg} / \mathrm{l} \mathrm{BA}$ and $1 \mathrm{mg} / \mathrm{l} \mathrm{NAA} ; 3 \mathrm{mg} / \mathrm{l} \mathrm{BA}$ and $1 \mathrm{mg} / \mathrm{l} \mathrm{NAA}$ were tested. The shoots were cultured on a rotary shaker (Altel, Poland) at $140 \mathrm{rpm}$, with a vibration amplitude of $35 \mathrm{~mm}$, in the same physical culture conditions as described above. The agitated cultures were maintained for 28 days ( 4 weeks), in three replications, 10 flasks per replication $(n=10)$, for each MS medium variant.

\section{Extraction and LC-DAD analysis}

The extraction was carried out as follows: $1 \mathrm{~g}$ of each dried (by lyophilization) and powdered (in a mortar) biomass was subjected (twice) to extraction with $50 \mathrm{ml}$ of boiling analytical grade methanol for $2 \mathrm{~h}$ under a reflux condenser. The combined extracts $(100 \mathrm{ml})$ were concentrated to dryness, and the residues were dissolved in $2 \mathrm{ml}$ of HPLC grade methanol (Merck, Germany). Respective experimental media were collected (40 ml) and lyophilized, and then dissolved in methanol $(5 \mathrm{ml})$. The qualitative and quantitative LC-DAD analyses were performed using Merck-Hitachi apparatus (autosampler L 2200, pump L 2130, column oven L 2350, diode array detector (DAD) L 2455) in a UV range of 200-400 nm (detection wavelength was set at $254 \mathrm{~nm}$ ), and a Purospher ${ }^{\circledR}$ RP-18e column (Merck, $250 \times 4 \mathrm{~mm}, 5 \mu \mathrm{m}$ ) thermostated at $25^{\circ} \mathrm{C}$. Gradient elution was applied acc. to Ellnain-Wojtaszek and Zgorka (1999); Sułkowska-Ziaja et al. (2017), the mobile phase was composed of methanol- $0.5 \%$ acetic acid $(1: 4, \mathrm{v} / \mathrm{v})$ and methanol. The flow rate was $1 \mathrm{ml} / \mathrm{min}$, injection volume was $10 \mu \mathrm{l}$. Quantification of the compounds was based on calibration curves by comparing the mean peak areas with those for standard concentrations. Reference standards of phenolic acids-benzoic acid derivatives: 3,4-dihydroxyphenylacetic, gallic, gentisic, p-hydroxybenzoic, protocatechuic, salicylic, syringic, vanillic acids; cinnamic acid derivatives: caffeic, o-coumaric, m-coumaric, p-coumaric, ferulic, hydrocaffeic, isoferulic, sinapic acids, and also a precursor of this group — cinnamic acid; and depsides: chlorogenic, neochlorogenic and rosmarinic acids (Sigma-Aldrich, USA). Reference compounds of flavonoids-aglycones: kaempferol, luteolin, quercetin, myricetin; glycosides: apigetrin, cynaroside, hyperoside, quercitrin, rutoside, trifolin and vitexin (SigmaAldrich, USA). A representative UV-LC chromatogram is shown in Fig. 1.

\section{Biotransformation of exogenously delivered hydroquinone}

\section{Experimental in vitro cultures}

In order to perform the biotransformation experiment, the agitated shoot cultures of A. arbutifolia and A. $\times$ prunifolia were cultured in $300 \mathrm{ml}$ Erlenmeyer flasks containing $100 \mathrm{ml}$ of standard MS liquid medium with $2 \mathrm{mg} / \mathrm{l} \mathrm{BA}$ and $2 \mathrm{mg} / \mathrm{l}$ NAA. The inoculum consisted of $4 \mathrm{~g}$ of fresh biomass. The cultures were agitated on a rotary shaker (Altel, Poland) at $140 \mathrm{rpm}$, with a vibration amplitude of $35 \mathrm{~mm}$, in the same physical conditions as described above.
Fig. 1 The representative LC-UV chromatogram $(\lambda=254 \mathrm{~nm})$ of a methanol extract of $A$. arbutifolia shoots cultivated on MS medium with $2 \mathrm{mg} / \mathrm{l} \mathrm{BA}$ and $1 \mathrm{mg} / \mathrm{l} \mathrm{NAA}$

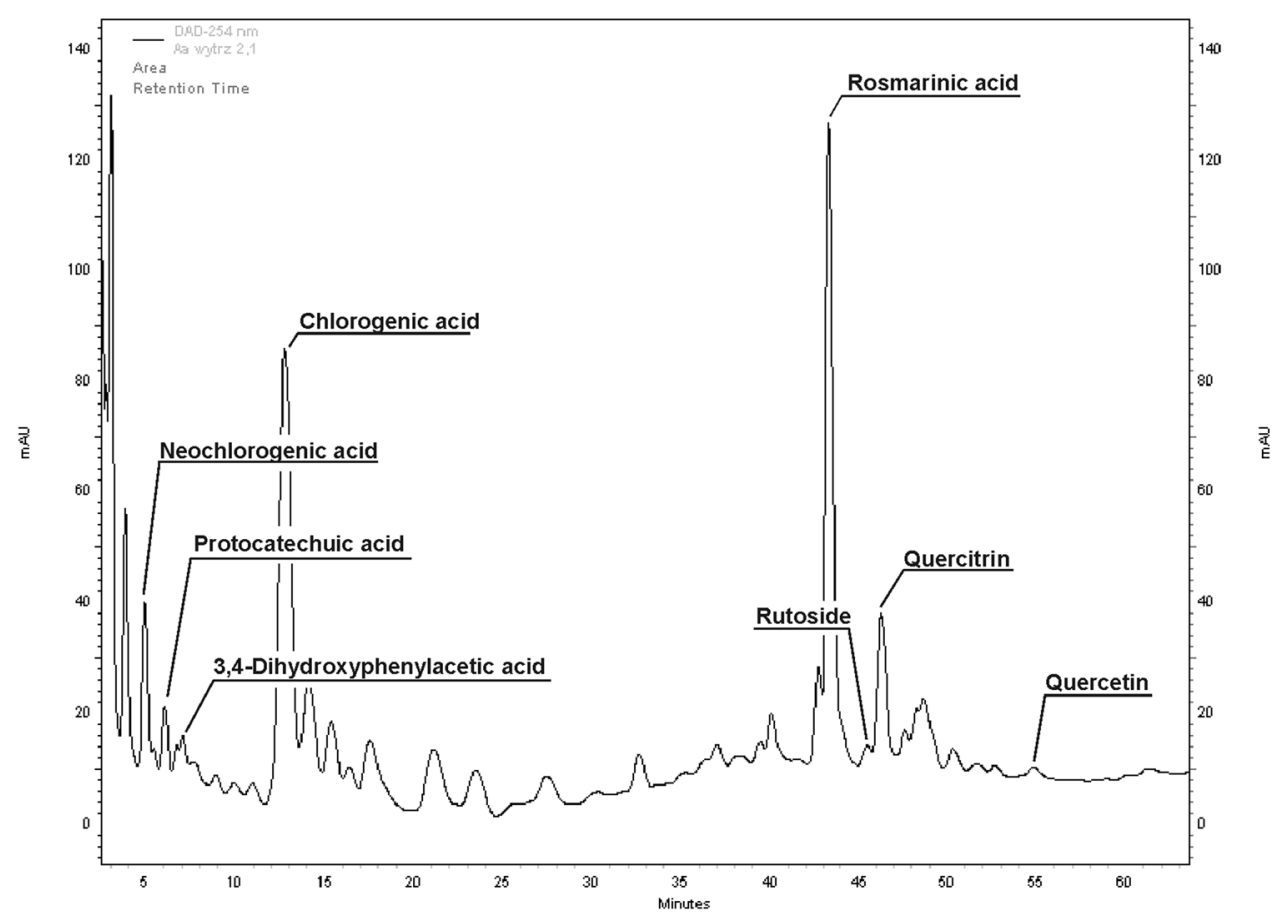


Hydroquinone (Merck, Germany) was introduced to the culture media as an aqueous solution ( 1 or $2 \mathrm{mg} / \mathrm{ml}) 14$ days after inoculation. It was administered into the culture flasks aseptically through a $0.22 \mu \mathrm{m}$ membrane filter (Merck-Millipore, Germany). Fresh medium $(100 \mathrm{ml})$ was also added to each flask ( $\mathrm{pH}$ 5.7). The final concentrations of hydroquinone were: $100,150,200,300$ and $400 \mathrm{mg} / \mathrm{l}$ of medium. Hydroquinone was administered in a single dose or in split doses as two or three portions added at $24 \mathrm{~h}$ intervals. Harvesting of the shoot biomass and culture media was carried out $24 \mathrm{~h}$ after the last dose of hydroquinone. The biomass was air dried (at $37^{\circ} \mathrm{C}$ ) and the media were lyophilized. The experimental combinations were run independently in three replications, $\mathrm{n}=10$, for each plant.

In order to calculate the efficiency of the biotransformation, the following formula was used: efficiency $=\mathrm{a} / \mathrm{b} \times 100 \%$, where ' $\mathrm{a}$ ' is the overall amount of arbutin produced per flask (in the biomass and in $200 \mathrm{ml}$ of medium); ' $b$ ' is the maximum amount of arbutin that can be theoretically obtained from the applied amount of hydroquinone (calculated from the molar masses of the compounds) acc. to Suzuki et al. (1987).

\section{Extraction and LC-DAD analysis}

One gram of each dried and powdered (in a mortar) biomass was subjected (twice) to extraction with $50 \mathrm{ml}$ of boiling analytical grade methanol for $4 \mathrm{~h}$ under a reflux condenser. The extracts $(100 \mathrm{ml})$ were evaporated to dryness, and the residues were dissolved in $2 \mathrm{ml}$ of HPLC grade methanol (Merck, Germany). The lyophilized media were also dissolved in HPLC grade methanol up to $5 \mathrm{ml}$.

The extracts were analyzed by the LC-DAD method of Štambergová et al. (1985). For chromatographic estimation, the same HPLC apparatus was used as described above. The applied separation method consisted of a mobile phase of methanol $\times$ water $(1: 9, \mathrm{v} / \mathrm{v})$ at a flow rate of $1 \mathrm{ml} /$ min. Arbutin and hydroquinone were detected at $285 \mathrm{~nm}$ (retention times: 3.8 and 5.6 min., respectively). Qualification and quantification were based on comparisons with reference standards (Sigma-Aldrich, USA). The amounts of the compounds were calculated from calibration curves by comparing the mean peak areas with those for standard concentrations. A representative UV-LC chromatogram is shown in Fig. 2.

\section{Statistical analysis}

Results are presented as the mean $\pm \mathrm{SD}$ of three independent determinations. Statistical significance of the differences was assessed by one-way ANOVA. Duncan's test was implemented to identify significant differences in the individual and total contents of estimated compounds,

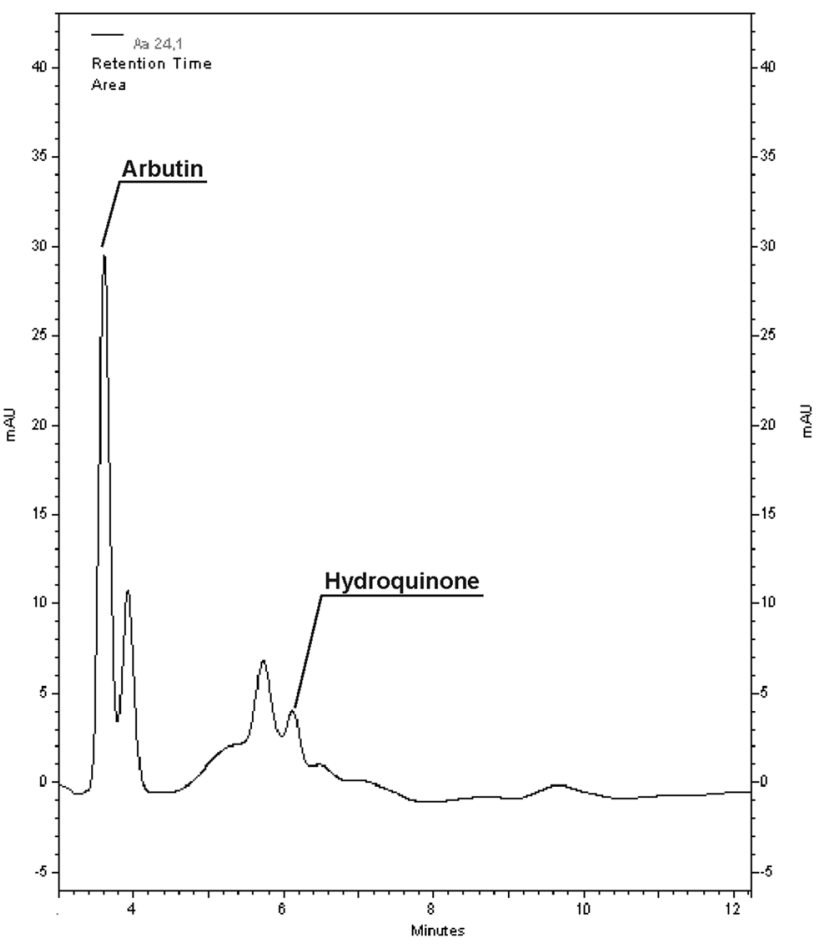

Fig. 2 The representative LC-UV chromatogram $(\lambda=285 \mathrm{~nm})$ of a methanol extract of $A$. arbutifolia shoots cultivated in vitro after experiment of biotransformation of hydroquinone into arbutin

total arbutin content and biotransformation efficiency. The differences were statistically significant when $p<0.05$. The analyses were performed using STATISTICA version 12 PL software package (StatSoft, Poland).

\section{Results}

\section{Biomass increments}

\section{Aronia arbutifolia cultures}

The shoot cultures of A. arbutifolia growing on the tested MS medium variants showed from 2.17- to 2.93-fold increases in dry biomass during 4-week growth cycles. The highest biomass growth was confirmed for MS medium containing $0.5 \mathrm{mg} / \mathrm{l} \mathrm{BA}$ and $2 \mathrm{mg} / \mathrm{l} \mathrm{NAA} \mathrm{(2.93-}$ fold) and $2 \mathrm{mg} / \mathrm{l} \mathrm{BA}$ and $2 \mathrm{mg} / \mathrm{l} \mathrm{NAA}$ (2.79-fold). The shoot cultures were characterized by varied morphology depending on the tested MS medium variant. The shoots growing on MS medium with a small amount of cytokinin $(0.5 \mathrm{mg} / \mathrm{l} \mathrm{BA}$ and $2 \mathrm{mg} / \mathrm{l} \mathrm{NAA})$ were elongated and less branched. The shoots growing on other tested MS media with higher amounts of BA were well branched but less elongated (Fig. 3). 


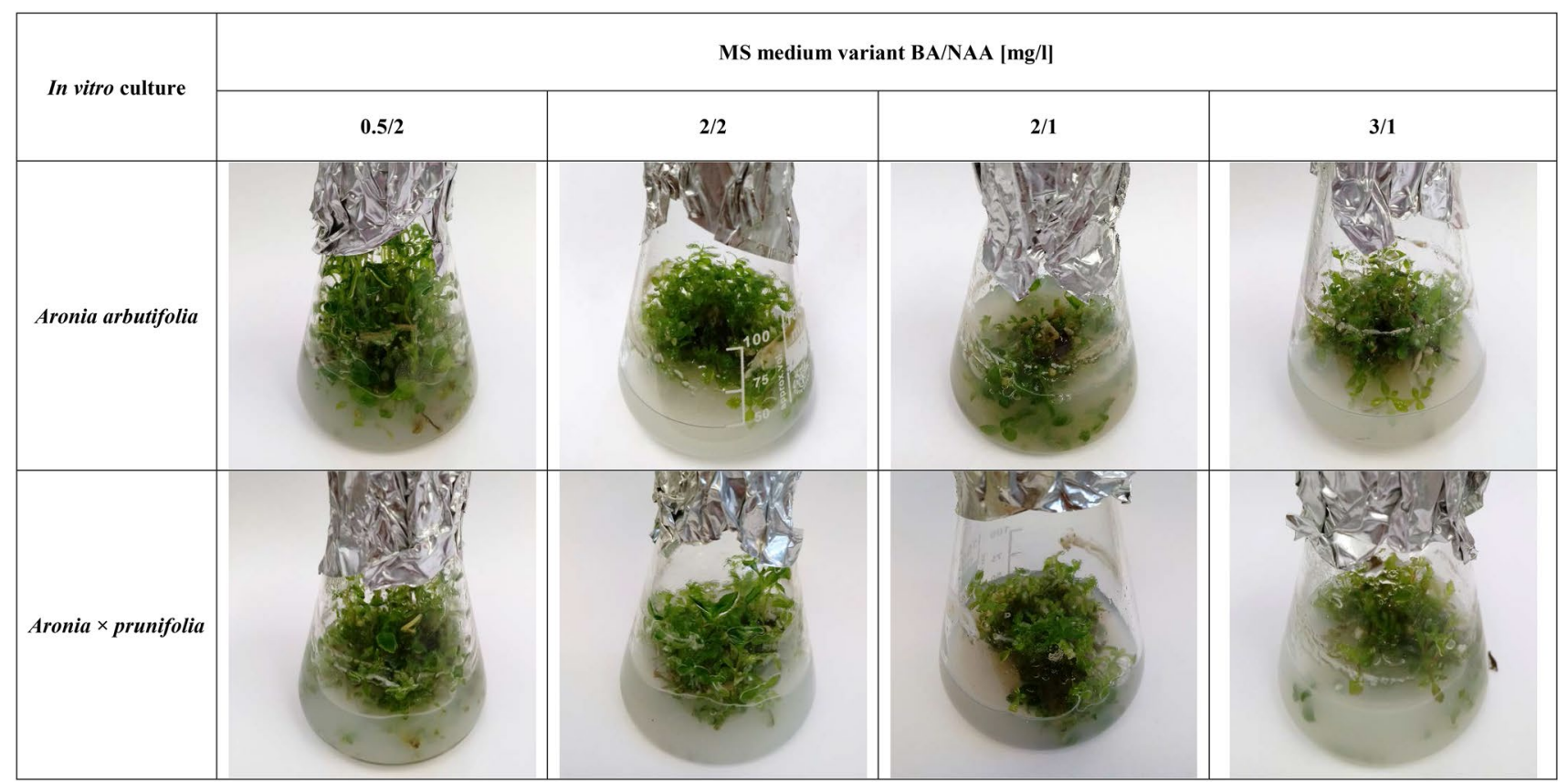

Fig. 3 The morphological appearance of A. arbutifolia and A. $\times$ prunifolia agitated shoot cultures cultivated on different MS media variants, after 4-weeks growth period

Table 1 Phenolic acid contents $(\mathrm{mg} / 100 \mathrm{~g} \mathrm{DW} \pm \mathrm{SD})$ in shoot extracts from agitated cultures of $A$. arbutifolia cultivated on tested MS medium variants and in the fruit extracts of soil-grown plant (acc. Szopa et al. 2018)

\begin{tabular}{|c|c|c|c|c|c|}
\hline \multirow[t]{2}{*}{ Estimated phenolic acids } & \multicolumn{4}{|c|}{ MS medium variant BA/NAA (mg/l) } & \multirow[t]{2}{*}{ Fruit } \\
\hline & $0.5 / 2$ & $2 / 2$ & $2 / 1$ & $3 / 1$ & \\
\hline Chlorogenic acid & $145.44 \pm 15.54^{\mathrm{a}}$ & $175.94 \pm 20.35^{\mathrm{b}}$ & $127.82 \pm 26.49^{\mathrm{c}}$ & $122.83 \pm 10.96^{\mathrm{c}}$ & $16.27 \pm 0.52^{\mathrm{d}}$ \\
\hline 3,4-Dihydroxyphenylacetic acid & $54.82 \pm 2.06^{\mathrm{a}}$ & $57.39 \pm 4.32^{\mathrm{a}}$ & $53.34 \pm 15.53^{\mathrm{a}}$ & $45.36 \pm 4.32^{\mathrm{b}}$ & $20.8 \pm 0.13^{c}$ \\
\hline Neochlorogenic acid & $17.73 \pm 6.73^{\mathrm{a}}$ & $23.32 \pm 0.60^{b}$ & $28.03 \pm 3.79^{b}$ & $25.48 \pm 3.37^{\mathrm{b}}$ & $92.26 \pm 3.26^{\mathrm{c}}$ \\
\hline Protocatechuic acid & $1.52 \pm 0.07^{\mathrm{a}}$ & $2.48 \pm 0.26^{\mathrm{b}}$ & $3.64 \pm 0.11^{\mathrm{c}}$ & $2.78 \pm 0.01^{\mathrm{b}}$ & $0.37 \pm 0.11^{\mathrm{d}}$ \\
\hline Rosmarinic acid & $102.70 \pm 7.44^{\mathrm{a}}$ & $78.57 \pm 10.60^{\mathrm{b}}$ & $147.98 \pm 9.88^{\mathrm{c}}$ & $132.49 \pm 30.03^{\mathrm{c}}$ & $16.24 \pm 1.34^{\mathrm{d}}$ \\
\hline Total content & $322.21 \pm 31.84^{\mathrm{a}}$ & $337.70 \pm 36.13^{\mathrm{b}}$ & $360.80 \pm 55.80^{\mathrm{c}}$ & $328.94 \pm 48.69^{\mathrm{a}}$ & $145.95 \pm 5.36^{\mathrm{d}}$ \\
\hline
\end{tabular}

Different letters indicate significant differences between means $(\mathrm{n}=10, p<0.05)$ based on Duncan's test

\section{Aronia $\times$ prunifolia cultures}

The shoot cultures of $A . \times$ prunifolia growing on the tested MS medium variants showed from 2.03- to 3.07-fold increases in dry biomass during 4-week growth cycles. The highest biomass growth was confirmed for MS medium containing $2 \mathrm{mg} / \mathrm{l} \mathrm{BA}$ and $2 \mathrm{mg} / \mathrm{l} \mathrm{NAA} \mathrm{(3.07-fold)} \mathrm{and} 0.5 \mathrm{mg} / \mathrm{l}$ BA and $2 \mathrm{mg} / \mathrm{l}$ NAA (3.02-fold). The shoot cultures were characterized by varied morphology depending on the tested MS medium variant. The shoots growing on MS medium with a small amount of cytokinin $(0.5 \mathrm{mg} / \mathrm{l} \mathrm{BA}$ and $2 \mathrm{mg} / \mathrm{l}$ NAA) were elongated and poorly branched, and had welldeveloped leaves. The shoots growing on other tested MS media with higher amounts of BA grew very close to each other and had small leaves (Fig. 3).

\section{Accumulation of phenolic acids}

\section{Aronia arbutifolia cultures}

Of the 20 compounds estimated, the extracts from the biomass of A. arbutifolia shoots grown on the four tested MS variants were all found to contain the same five phenolic acids; three depsides-chlorogenic acid, neochlorogenic acid and rosmarinic acid, and 3,4-dihydroxyphenylacetic acid and protocatechuic acid (Table 1). The amounts of 
the individual compounds varied greatly, depending on the variant of the growing medium, from 1.27 to 2.40 -fold. The largest amounts that accumulated in the shoots were those of chlorogenic acid, ranging from 122.83 to $175.94 \mathrm{mg} / 100 \mathrm{~g}$ DW. The maximum amount of this depside was found on the medium containing $2 \mathrm{mg} / \mathrm{l} \mathrm{BA}$ and $2 \mathrm{mg} / \mathrm{l} \mathrm{NAA}$. Another compound that was also accumulated in large amounts in the shoots was rosmarinic acid. Its amounts varied within even wider limits, from 78.57 to $147.98 \mathrm{mg} / 100 \mathrm{~g}$ DW. The highest amount was found on the MS medium containing $2 \mathrm{mg} / 1$ BA and $1 \mathrm{mg} / \mathrm{l} \mathrm{NAA}$. The confirmed amounts of 3,4-dihydroxyphenylacetic acid were of a different order of magnitude; they did not exceed $58 \mathrm{mg} / 100 \mathrm{~g} \mathrm{DW}$, and increased about 1.27-fold, depending on the variant of MS medium. The maximum content of $57.39 \mathrm{mg} / 100 \mathrm{~g}$ DW was found on the medium containing $2 \mathrm{mg} / \mathrm{l}$ each of cytokinin and auxin. Neochlorogenic acid was accumulated in even smaller amounts, from 17.73 to $28.03 \mathrm{mg} / 100 \mathrm{~g} \mathrm{DW}$. The highest content was confirmed on the medium containing $2 \mathrm{mg} / \mathrm{l}$ BA and $1 \mathrm{mg} / \mathrm{l}$ NAA. The amounts of protocatechuic acid were very low (max. $3.64 \mathrm{mg} / 100 \mathrm{~g}$ DW). The total amounts of phenolic acids obtained from the biomass of shoots were significant. They ranged from 322.21 to $360.80 \mathrm{mg} / 100 \mathrm{~g}$ DW. The maximum content was found on the MS variant containing $2 \mathrm{mg} / \mathrm{l} \mathrm{BA}$ and $1 \mathrm{mg} / \mathrm{l} \mathrm{NAA} \mathrm{(Table} \mathrm{1).} \mathrm{The} \mathrm{phe-}$ nolic acids were not present in the tested media.

\section{Aronia $\times$ prunifolia cultures}

Of the 20 compounds estimated in the extracts of $A . \times$ prunifolia shoots grown on the four MS variants tested, the analysis confirmed in all of them the presence of also five phenolic acids, three depsides-chlorogenic acid, neochlorogenic acid and rosmarinic acid, and 3,4-dihydroxyphenylacetic acid and protocatechuic acid (Table 2). Depending on the composition of the culture media, the amounts of the individual compounds increased within the range from 1.48 to 2.64 -fold. The main, quantitatively dominant metabolite was chlorogenic acid. Its amounts ranged from 142.97 to
$260.34 \mathrm{mg} / 100 \mathrm{~g}$ DW. The maximum content was confirmed on the medium containing $3 \mathrm{mg} / \mathrm{l} \mathrm{BA}$ and $1 \mathrm{mg} / \mathrm{l} \mathrm{NAA}$. Another compound that was accumulated in large quantities in the cultivated biomass was rosmarinic acid (amounts in the range of 97.80-225.71 mg/100 g DW). On two MS variants, the highest maximal amounts of this metabolite were almost identical—225.71 and $225.26 \mathrm{mg} / 100 \mathrm{~g} \mathrm{DW}$ (variants containing $2 \mathrm{mg} / \mathrm{l} \mathrm{BA}$ and $1 \mathrm{mg} / \mathrm{l} \mathrm{NAA}$, and $3 \mathrm{mg} / \mathrm{l} \mathrm{BA}$ and $1 \mathrm{mg} / \mathrm{l} \mathrm{NAA}$ ). 3,4-Dihydroxyphenylacetic acid was accumulated in smaller amounts, not exceeding $100 \mathrm{mg} / 100 \mathrm{~g} \mathrm{DW}$. The content ranged from 66.80 to $98.65 \mathrm{mg} / 100 \mathrm{~g}$ DW. The maximum amount of this acid was confirmed on the medium containing $3 \mathrm{mg} / \mathrm{l} \mathrm{BA}$ and $1 \mathrm{mg} / \mathrm{l}$ NAA. Neochlorogenic acid was accumulated in even smaller amounts (26.84-70.91 mg/100 g DW). The maximum content was found on the MS medium containing $3 \mathrm{mg} / \mathrm{l} \mathrm{BA}$ and $1 \mathrm{mg} / \mathrm{l}$ NAA. Protocatechuic acid was accumulated in very small quantities (max. $5.50 \mathrm{mg} / 100 \mathrm{~g} \mathrm{DW}$ ).

The total amounts of phenolic acids were high (339.91-659.51 mg/100 g DW). The maximum content was confirmed in extracts from the biomass of shoots grown on the medium containing $3 \mathrm{mg} / \mathrm{l} \mathrm{BA}$ and $1 \mathrm{mg} / \mathrm{l}$ NAA (Table 2). The phenolic acids were not detected in the media samples.

\section{Accumulation of flavonoids}

\section{Aronia arbutifolia cultures}

Irrespective of the composition of the growing media, the analysis of extracts from A. arbutifolia shoots (analyzed for 11 flavonoid compounds) revealed the presence of quercetin (a flavonoid aglycone) and two of its glycoside conjugates-quercitrin and rutoside (Table 3). The quantitatively predominant metabolite was quercitrin. Its amounts on each MS variant were considerable (35.85-41.14 mg/100 g DW). The highest content was found on the MS variants containing $0.5 \mathrm{mg} / \mathrm{l} \mathrm{BA}$ and $2 \mathrm{mg} / \mathrm{l} \mathrm{NAA}$. The estimated amounts of rutoside were several times lower, equal to

Table 2 Phenolic acid contents $(\mathrm{mg} / 100 \mathrm{~g}$ DW $\pm \mathrm{SD})$ in shoot extracts from agitated cultures of $A . \times$ prunifolia cultivated on tested MS medium variants and in the fruit extracts of soil-grown plant (acc. Szopa et al. 2018)

\begin{tabular}{|c|c|c|c|c|c|}
\hline \multirow[t]{2}{*}{ Estimated phenolic acids } & \multicolumn{4}{|c|}{ MS medium variant BA/NAA (mg/l) } & \multirow[t]{2}{*}{ Fruit } \\
\hline & $0.5 / 2$ & $2 / 2$ & $2 / 1$ & $3 / 1$ & \\
\hline Chlorogenic acid & $142.97 \pm 10.17^{\mathrm{a}}$ & $180.35 \pm 12.14^{\mathrm{b}}$ & $223.93 \pm 24.33^{\mathrm{c}}$ & $260.34 \pm 15.38^{\mathrm{d}}$ & $273.45 \pm 4.69^{\mathrm{d}}$ \\
\hline 3,4-Dihydroxyphenylacetic acid & $66.80 \pm 11.76^{\mathrm{a}}$ & $75.37 \pm 9.50^{\mathrm{b}}$ & $78.67 \pm 10.23^{\mathrm{b}}$ & $98.65 \pm 1.49^{c}$ & $4.29 \pm 0.14^{\mathrm{d}}$ \\
\hline Neochlorogenic acid & $26.84 \pm 9.47^{\mathrm{a}}$ & $42.32 \pm 5.15^{\mathrm{b}}$ & $68.23 \pm 3.26^{\mathrm{c}}$ & $70.91 \pm 3.57^{\mathrm{c}}$ & $212.56 \pm 1.6^{\mathrm{d}}$ \\
\hline Protocatechuic acid & $5.50 \pm 1.33^{\mathrm{a}}$ & $3.23 \pm 0.10^{\mathrm{b}}$ & $4.12 \pm 0.21^{\mathrm{c}}$ & $4.35 \pm 0.16^{\mathrm{c}}$ & $4.42 \pm 0.12^{\mathrm{c}}$ \\
\hline Rosmarinic acid & $97.80 \pm 7.22^{\mathrm{a}}$ & $120.20 \pm 19.37^{b}$ & $225.71 \pm 24.33^{\mathrm{c}}$ & $225.26 \pm 25.12^{\mathrm{c}}$ & $9.15 \pm 0.98^{d}$ \\
\hline Total content & $339.91 \pm 39.95^{\mathrm{a}}$ & $421.47 \pm 46.26^{\mathrm{b}}$ & $600.67 \pm 53.85^{\mathrm{c}}$ & $659.51 \pm 45.72^{\mathrm{d}}$ & $503.87 \pm 7.53^{\mathrm{e}}$ \\
\hline
\end{tabular}

Different letters indicate significant differences between means $(\mathrm{n}=10, p<0.05)$ based on Duncan's test 
Table 3 Flavonoid contents $(\mathrm{mg} / 100 \mathrm{~g} \mathrm{DW} \pm \mathrm{SD})$ in shoot extracts from agitated cultures of $A$. arbutifolia cultivated on tested MS medium variants and in the fruit extracts of soil-grown plant (acc. Szopa et al. 2018)

\begin{tabular}{lrrrll}
\hline Estimated flavonoids & \multicolumn{2}{l}{ MS medium variant BA/NAA (mg/l) } & \multirow{2}{*}{ Fruit } \\
\cline { 2 - 5 } & \multicolumn{1}{c}{$0.5 / 2$} & \multicolumn{2}{l}{$2 / 2$} & \multicolumn{2}{l}{$3 / 1$} \\
\hline Quercetin & $18.72 \pm 3.59^{\mathrm{a}}$ & $14.75 \pm 1.74^{\mathrm{b}}$ & $15.53 \pm 0.23^{\mathrm{b}}$ & $16.18 \pm 4.19^{\mathrm{b}}$ & $31.83 \pm 3.30^{\mathrm{c}}$ \\
Quercitrin & $41.14 \pm 6.85^{\mathrm{a}}$ & $40.25 \pm 0.09^{\mathrm{a}}$ & $37.16 \pm 0.03^{\mathrm{b}}$ & $35.85 \pm 8.04^{\mathrm{b}}$ & nd \\
Rutoside & $5.39 \pm 2.18^{\mathrm{a}}$ & $2.87 \pm 0.80^{\mathrm{b}}$ & $6.35 \pm 2.44^{\mathrm{c}}$ & $9.08 \pm 2.42^{\mathrm{d}}$ & nd \\
Total content & $65.26 \pm 12.63^{\mathrm{a}}$ & $57.87 \pm 2.62^{\mathrm{b}}$ & $59.03 \pm 2.69^{\mathrm{b}}$ & $61.11 \pm 14.65^{\mathrm{a}}$ & $31.83 \pm 3.30^{\mathrm{c}}$ \\
\hline
\end{tabular}

Different letters indicate significant differences between means $(\mathrm{n}=10, p<0.05)$ based on Duncan's test nd Not detected
5.39-9.08 mg/100 g DW. The amounts of the aglycone (quercetin) did not exceed $19 \mathrm{mg} / 100 \mathrm{~g} \mathrm{DW}$. The total amounts of the flavonoid compounds differed only 1.13fold, on the individual MS variants. The largest amounts, equal to 65.26 and $61.11 \mathrm{mg} / 100 \mathrm{~g} \mathrm{DW}$, were confirmed on the media containing, respectively, $0.5 \mathrm{mg} / \mathrm{l} \mathrm{BA}$ and $2 \mathrm{mg} / 1$ NAA, and $3 \mathrm{mg} / \mathrm{l} \mathrm{BA}$ and $1 \mathrm{mg} / \mathrm{l} \mathrm{NAA}$ (Table 3 ). The studied flavonoids were not detected in the media samples.

\section{Aronia $\times$ prunifolia cultures}

In terms of flavonoid compounds, the analyzed extracts from A. $\times$ prunifolia shoots were found to have the same qualitative composition regardless of the MS variant. The analysis confirmed the presence of the same three compounds whose presence had been recorded in extracts from the shoots of A. arbutifolia-quercetin, quercitrin, and rutoside (Table 4). The main metabolite was quercitrin. Its amounts ranged from about 32 to $48 \mathrm{mg} / 100 \mathrm{~g} \mathrm{DW}$, depending on the composition of the medium. On the medium containing $3 \mathrm{mg} / \mathrm{l}$ BA and $1 \mathrm{mg} / \mathrm{l} \mathrm{NAA}$, the quercitrin content was markedly higher (the max. content was $47.86 \mathrm{mg} / 100 \mathrm{~g} \mathrm{DW}$ ) than on the other three MS variants (32.36-36.60 mg/100 g DW). The amounts of rutoside were several times lower than those of quercitrin (10.21-13.44 mg/100 g DW). The confirmed amounts of quercetin changed within a narrow range, from 14.93 to $17.03 \mathrm{mg} / 100 \mathrm{~g}$ DW. The maximum amounts of both rutoside and quercetin were found on the medium supplemented with $3 \mathrm{mg} / \mathrm{l} \mathrm{BA}$ and $1 \mathrm{mg} / \mathrm{l}$ NAA. On the medium of this composition, the total amount of the three flavonoid compounds was also the highest—equal to $78.34 \mathrm{mg} / 100 \mathrm{~g}$
DW (Table 4). The flavonoids were not present in the tested media.

\section{Biotransformation of hydroquinone into arbutin: effect of optimization}

\section{Aronia arbutifolia cultures}

In the experiment, there were no adverse effects of the applied doses of hydroquinone on biomass growth increments; the average increases in dry biomass growth fluctuated around threefold during the 17-day growth period (Fig. 4). Only in the case of the highest doses of the precursor added in one portion $(300,400 \mathrm{mg} / \mathrm{l})$ did we notice some inhibition in the growth of the biomass (2.49 and 2.21-fold increments, respectively), and a darkening of the biomass colour.

Cells from A. arbutifolia cultures in vitro exhibited the ability to perform bioconversion of hydroquinone into its $\beta$-D-glucoside, arbutin. Arbutin was accumulated mainly in the cultivated biomass (max. $92.08-93.43 \mathrm{mg} / \mathrm{g}$ DW for $150-300 \mathrm{mg} / \mathrm{l}$ dose of hydroquinone divided into three portions).

Higher accumulation of the product in the media was found when the precursor was administered in single doses (Table 5). The total amount of the product (in the biomass and culture media) was clearly dependent on the concentration of the precursor, and fell within the range from 27.78 to $83.55 \mathrm{mg} / \mathrm{g}$ DW. The amounts of arbutin in the cultured biomass varied within wide limits, from 20.56 to
Table 4 Flavonoid contents $(\mathrm{mg} / 100 \mathrm{~g} \mathrm{DW} \pm \mathrm{SD})$ in shoot extracts from agitated cultures of A. × prunifolia cultivated on tested MS medium variants and in the fruit extracts of soil-grown plant (acc. Szopa et al. 2018)

\begin{tabular}{llllll}
\hline Estimated flavonoids & \multicolumn{2}{l}{ MS medium variant BA/NAA $(\mathrm{mg} / \mathrm{l})$} & \multirow{2}{*}{ Fruit } \\
\cline { 2 - 5 } & $0.5 / 2$ & $2 / 2$ & $2 / 1$ & $3 / 1$ & \\
\hline Quercetin & $15.22 \pm 0.75^{\mathrm{a}}$ & $14.93 \pm 0.04^{\mathrm{a}}$ & $14.94 \pm 0.06^{\mathrm{a}}$ & $17.03 \pm 0.07^{\mathrm{b}}$ & $44.26 \pm 3.60^{\mathrm{c}}$ \\
Quercitrin & $32.36 \pm 3.21^{\mathrm{a}}$ & $34.71 \pm 0.02^{\mathrm{b}}$ & $36.60 \pm 0.02^{\mathrm{b}}$ & $47.86 \pm 0.03^{\mathrm{c}}$ & nd \\
Rutoside & $11.60 \pm 2.72^{\mathrm{a}}$ & $10.21 \pm 0.22^{\mathrm{b}}$ & $11.33 \pm 0.15^{\mathrm{a}}$ & $13.44 \pm 0.21^{\mathrm{c}}$ & nd \\
Total content & $59.18 \pm 6.68^{\mathrm{a}}$ & $59.85 \pm 0.27^{\mathrm{a}}$ & $62.87 \pm 0.23^{\mathrm{b}}$ & $78.34 \pm 0.32^{\mathrm{c}}$ & $44.26 \pm 3.60^{\mathrm{d}}$ \\
\hline
\end{tabular}

Different letters indicate significant differences between means $(\mathrm{n}=10, p<0.05)$ based on Duncan's test nd Not detected 
Fig. 4 The appearance of $A$. arbutifolia and $A . \times$ prunifolia agitated shoot cultures - the flasks with the biomasses after treatment of $100 \mathrm{mg} / \mathrm{l}$ doses of hydroquinone divided into three portions, where the highest biotransformation efficiency was obtained

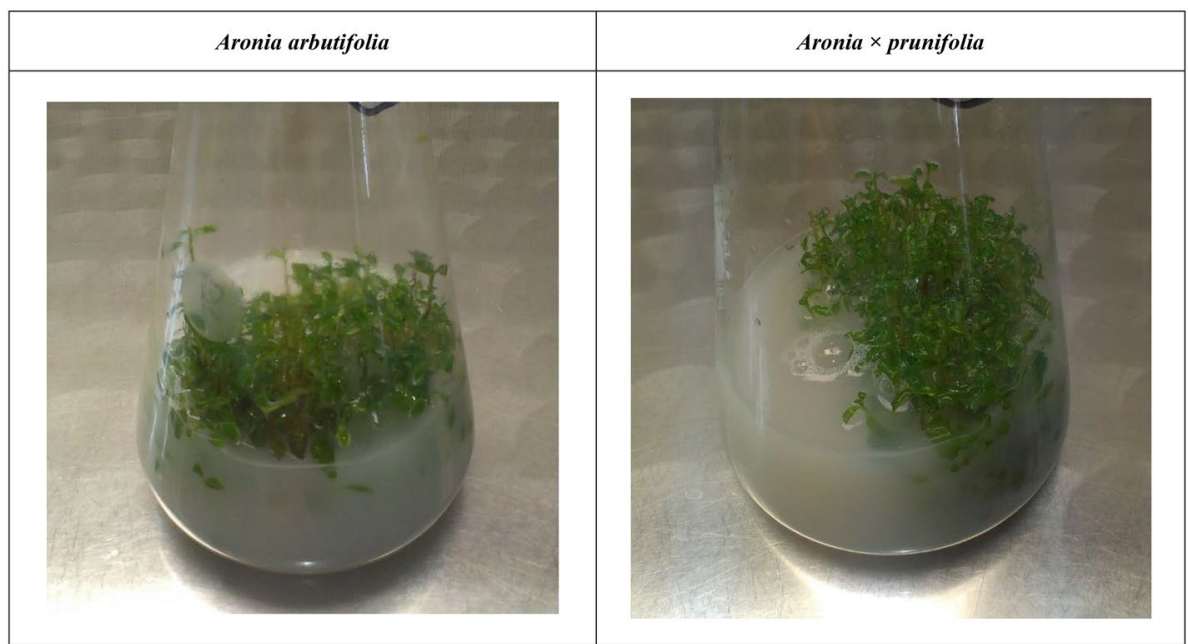

Table 5 Effects of optimization of bioconversion of hydroquinone as the precursor into arbutin in shoot cultures of A. arbutifolia

\begin{tabular}{|c|c|c|c|c|c|c|c|}
\hline \multirow[t]{2}{*}{$\begin{array}{l}\text { Concentration of } \\
\text { precursor }(\mathrm{mg} / \mathrm{l})\end{array}$} & \multirow[t]{2}{*}{$\begin{array}{l}\text { Method of precursor } \\
\text { supply }\end{array}$} & \multirow{2}{*}{$\begin{array}{l}\text { Total arbutin } \\
\text { content }(\mathrm{mg} / \mathrm{g} \\
\mathrm{DW} \pm \mathrm{SD})^{*}\end{array}$} & \multicolumn{2}{|c|}{$\begin{array}{l}\text { Arbutin content in } \\
\text { biomass }\end{array}$} & \multicolumn{2}{|c|}{$\begin{array}{l}\text { Arbutin content in } \\
\text { medium }\end{array}$} & \multirow[t]{2}{*}{$\begin{array}{l}\text { Biotransformation } \\
\text { efficiency }(\% \pm S D)\end{array}$} \\
\hline & & & (mg/g DW) & $(\%)$ & $(\mathrm{mg} / \mathrm{l} \mathrm{DW})$ & $(\%)$ & \\
\hline \multirow[t]{3}{*}{100} & Single dose & $27.78 \pm 5.17^{\mathrm{a}}$ & 20.56 & 75.02 & 35.41 & 24.98 & $59.74 \pm 10.96^{\mathrm{a}}$ \\
\hline & 2 Portions & $30.72 \pm 1.03^{\mathrm{a}}$ & 27.52 & 89.70 & 15.61 & 10.30 & $63.86 \pm 9.05^{\mathrm{b}}$ \\
\hline & 3 Portions & $32.05 \pm 1.66^{\mathrm{b}}$ & 28.52 & 88.97 & 19.46 & 11.03 & $74.33 \pm 4.76^{\mathrm{c}}$ \\
\hline \multirow[t]{3}{*}{150} & Single dose & $41.46 \pm 7.33^{\mathrm{a}}$ & 37.72 & 91.30 & 17.44 & 8.70 & $56.31 \pm 8.31^{\mathrm{a}}$ \\
\hline & 2 Portions & $43.45 \pm 5.11^{\mathrm{a}}$ & 37.63 & 87.11 & 31.03 & 12.89 & $67.61 \pm 13.36^{\mathrm{b}}$ \\
\hline & 3 Portions & $45.34 \pm 2.16^{\mathrm{a}}$ & 41.72 & 92.08 & 19.46 & 7.92 & $69.01 \pm 7.30^{\mathrm{b}}$ \\
\hline \multirow[t]{3}{*}{200} & Single dose & $45.09 \pm 5.79^{\mathrm{a}}$ & 38.09 & 84.47 & 33.98 & 15.53 & $46.12 \pm 3.49^{\mathrm{a}}$ \\
\hline & 2 Portions & $46.50 \pm 6.89^{\mathrm{a}}$ & 37.82 & 82.12 & 41.65 & 17.88 & $49.08 \pm 11.27^{\mathrm{a}}$ \\
\hline & 3 Portions & $65.62 \pm 1.13^{\mathrm{b}}$ & 61.20 & 93.43 & 21.01 & 6.57 & $67.37 \pm 13.74^{b}$ \\
\hline \multirow[t]{3}{*}{300} & Single dose & $38.87 \pm 1.10^{\mathrm{a}}$ & 31.04 & 80.07 & 35.60 & 19.93 & $25.10 \pm 3.30^{\mathrm{a}}$ \\
\hline & 2 Portions & $56.62 \pm 8.23^{\mathrm{b}}$ & 47.95 & 86.04 & 42.89 & 13.96 & $43.15 \pm 15.88^{b}$ \\
\hline & 3 Portions & $58.47 \pm 4.05^{\mathrm{b}}$ & 54.54 & 93.32 & 23.14 & 6.68 & $48.63 \pm 4.59^{c}$ \\
\hline \multirow[t]{3}{*}{400} & Single dose & $29.28 \pm 1.86^{\mathrm{a}}$ & 22.24 & 75.97 & 29.64 & 24.03 & $13.00 \pm 0.13^{\mathrm{a}}$ \\
\hline & 2 Portions & $43.25 \pm 5.82^{\mathrm{b}}$ & 39.53 & 91.95 & 18.44 & 8.05 & $24.13 \pm 9.94^{\mathrm{b}}$ \\
\hline & 3 Portions & $83.55 \pm 4.47^{\mathrm{c}}$ & 71.00 & 85.87 & 65.72 & 14.13 & $49.01 \pm 14.80^{c}$ \\
\hline
\end{tabular}

*Sum of content in the biomass and in the medium

Different letters indicate significant differences between means $(n=3, p<0.05)$ based on Duncan's test

$71.00 \mathrm{mg} / \mathrm{g} \mathrm{DW}$, and in the media from 15.61 to $65.72 \mathrm{mg} / \mathrm{l}$ of medium. In the case of single low doses of hydroquinone $(100,200 \mathrm{mg} / \mathrm{l})$, the total arbutin content increased from $27.78 \mathrm{mg} / \mathrm{g}$ DW $(100 \mathrm{mg} / \mathrm{l})$ to $45.09 \mathrm{mg} / \mathrm{g}$ DW $(200 \mathrm{mg} / \mathrm{l})$. With the highest single doses of hydroquinone $(300$ and $400 \mathrm{mg} / \mathrm{l})$, the arbutin content dropped to 38.87 and $29.28 \mathrm{mg} / \mathrm{g}$ DW, respectively.

Splitting the doses of hydroquinone into portions favoured the biotransformation process; 1.09 - to 2.85 -fold increase in total arbutin content was found in the biomass and medium. The beneficial effect of splitting hydroquinone doses was particularly pronounced at the higher concentrations of the precursor (300 and $400 \mathrm{mg} / \mathrm{l})$. The addition of a $400 \mathrm{mg} / \mathrm{l}$ dose of the precursor divided into three portions resulted in the highest total arbutin content, equal to $83.55 \mathrm{mg} / 100 \mathrm{~g}$ DW.

The efficiency of the process of biotransformation of hydroquinone into arbutin ranged from 13.00 to $74.33 \%$. When hydroquinone was administered in single doses, only at the low concentrations (100 and $150 \mathrm{mg} / \mathrm{l})$ was the efficiency of the process similar (59.74 and 56.31\%). With higher undivided (full) doses of hydroquinone, the efficiency of the process decreased very markedly, from 46.12 to $13.00 \%$. Splitting hydroquinone doses into portions markedly increased 
the efficiency of the biotransformation, both at the low and high concentrations. The beneficial effect of splitting hydroquinone doses was particularly evident at the higher concentrations (200-400 mg/l). Administering hydroquinone in portions increased the efficiency by as much as fourfold. The highest efficiency of the process was obtained after administering the smallest doses (100-200 mg/l) divided into three portions (74.33-67.37\%) (Fig. 4). With the higher doses of hydroquinone (300 and $400 \mathrm{mg} / \mathrm{l}$ ), despite dividing them into three portions, the efficiency of the process did not exceed $50 \%$.

\section{A. $\times$ prunifolia cultures}

In the experiment, there were no adverse effects of the applied doses of hydroquinone on biomass growth increments; the average increases in dry biomass growth fluctuated around fivefold during the 17-day growth period (Fig. 4). Moreover, in the case of the addition of larger portions of hydroquinone $(300,400 \mathrm{mg} / \mathrm{l})$, we did not notice any inhibition in the growth of the biomass, only a slight darkening of the biomass colour.

Cells from A. $\times$ prunifolia shoot cultures also transformed hydroquinone into arbutin. The product was accumulated mainly in the biomass (max. $99.16 \%$ for a $300 \mathrm{mg} / \mathrm{l}$ dose of hydroquinone divided into three portions) (Table 6). The arbutin content in the media was low; it was about $10 \%$ at the lowest concentrations of hydroquinone $(100 \mathrm{mg} / \mathrm{l})$ and decreased (to 0.84 and $3.66 \%$ ) with increasing amounts of the precursor $(300,400 \mathrm{mg} / \mathrm{l})$. The total amount of the product in the biomass and the media changed depending on the concentration of hydroquinone. The arbutin content in the cultured biomass ranged from 21.45 to $70.85 \mathrm{mg} / \mathrm{g}$ DW, and in the media from 3.98 to $40.03 \mathrm{mg} / \mathrm{l}$ of medium. Following the administration of single doses of hydroquinone, the arbutin content in the biomass gradually increased, from $23.98 \mathrm{mg} / \mathrm{g}$ DW (100 mg/l) to $46.73 \mathrm{mg} / \mathrm{g}$ DW (400 mg/l).

The splitting of hydroquinone doses into portions was favourable to the accumulation of arbutin in the biomass. Following the supplementation of the media with hydroquinone in concentrations of $150-400 \mathrm{mg} / \mathrm{l}$, there was an increase, between 1.71 and 3.30-fold, in the total arbutin content in the biomass and medium.

The maximum total arbutin content in the biomass and the medium, equal to $73.62 \mathrm{mg} / \mathrm{g} \mathrm{DW}$, was confirmed after the application of the highest tested dose of hydroquinone $(400 \mathrm{mg} / \mathrm{l})$ divided into three portions.

The efficiency of the process ranged from 33.37 to $85.73 \%$. When the culture media were supplemented with single, full doses of hydroquinone, the efficiency gradually decreased with increasing concentration of hydroquinone (from 67.94 to $33.37 \%$ ). Administering the precursor in split doses resulted in an increase of up to two times in the effectiveness of the biotransformation process. The maximum efficiency of the process was found after administering the smallest doses of the precursor $(100$ and $150 \mathrm{mg} / \mathrm{l})$

Table 6 Effects of optimization of bioconversion of hydroquinone as the precursor into arbutin in shoot cultures of A.× prunifolia

\begin{tabular}{|c|c|c|c|c|c|c|c|}
\hline \multirow[t]{2}{*}{$\begin{array}{l}\text { Concentration of } \\
\text { precursor }(\mathrm{mg} / \mathrm{l})\end{array}$} & \multirow[t]{2}{*}{$\begin{array}{l}\text { Method of precursor } \\
\text { supply }\end{array}$} & \multirow[t]{2}{*}{$\begin{array}{l}\text { Total arbutin content } \\
\left(\mathrm{mg} / \mathrm{g} \mathrm{DW}_{ \pm} \mathrm{SD}\right)^{*}\end{array}$} & \multicolumn{2}{|c|}{$\begin{array}{l}\text { Arbutin content in } \\
\text { biomass }\end{array}$} & \multicolumn{2}{|c|}{$\begin{array}{l}\text { Arbutin content in } \\
\text { medium }\end{array}$} & \multirow[t]{2}{*}{$\begin{array}{l}\text { Biotransformation } \\
\text { efficiency }(\% \pm \mathrm{SD}\end{array}$} \\
\hline & & & (mg/g DW) & $(\%)$ & $(\mathrm{mg} / \mathrm{l} \mathrm{DW})$ & $(\%)$ & \\
\hline \multirow[t]{3}{*}{100} & Single dose & $23.98 \pm 2.21^{\mathrm{a}}$ & 21.45 & 89.70 & 16.61 & 10.30 & $67.94 \pm 10.19^{\mathrm{a}}$ \\
\hline & 2 Portions & $24.15 \pm 2.87^{\mathrm{a}}$ & 23.15 & 95.87 & 7.45 & 4.13 & $75.94 \pm 3.54^{b}$ \\
\hline & 3 Portions & $26.34 \pm 1.34^{\mathrm{b}}$ & 25.10 & 95.37 & 9.43 & 4.63 & $85.73 \pm 10.42^{c}$ \\
\hline \multirow[t]{3}{*}{150} & Single dose & $25.50 \pm 5.06^{\mathrm{a}}$ & 23.35 & 92.11 & 12.92 & 7.89 & $46.03 \pm 9.61^{\mathrm{a}}$ \\
\hline & 2 Portions & $29.49 \pm 5.15^{\mathrm{b}}$ & 28.06 & 95.17 & 11.59 & 4.83 & $67.42 \pm 9.74^{b}$ \\
\hline & 3 Portions & $40.63 \pm 10.57^{c}$ & 35.08 & 86.23 & 40.03 & 13.77 & $81.66 \pm 7.40^{\mathrm{c}}$ \\
\hline \multirow[t]{3}{*}{200} & Single dose & $36.31 \pm 11.05^{\mathrm{a}}$ & 34.58 & 95.18 & 12.35 & 4.82 & $54.02 \pm 7.89^{\mathrm{a}}$ \\
\hline & 2 Portions & $37.17 \pm 9.39^{\mathrm{a}}$ & 34.58 & 92.99 & 19.65 & 7.01 & $59.06 \pm 2.91^{\mathrm{b}}$ \\
\hline & 3 Portions & $38.13 \pm 5.63^{\mathrm{a}}$ & 36.60 & 95.98 & 12.63 & 4.02 & $66.16 \pm 2.62^{\mathrm{c}}$ \\
\hline \multirow[t]{3}{*}{300} & Single dose & $38.36 \pm 8.09^{\mathrm{a}}$ & 35.32 & 92.05 & 21.07 & 7.95 & $37.24 \pm 1.36^{\mathrm{a}}$ \\
\hline & 2 Portions & $56.90 \pm 2.18^{\mathrm{b}}$ & 54.04 & 95.06 & 20.00 & 4.94 & $56.89 \pm 8.06^{\mathrm{b}}$ \\
\hline & 3 Portions & $58.65 \pm 1.59^{c}$ & 58.14 & 99.16 & 3.98 & 0.84 & $66.27 \pm 9.35^{\mathrm{c}}$ \\
\hline \multirow[t]{3}{*}{400} & Single dose & $46.73 \pm 5.50^{\mathrm{a}}$ & 44.92 & 96.34 & 11.60 & 3.66 & $33.37 \pm 7.91^{\mathrm{a}}$ \\
\hline & 2 Portions & $67.55 \pm 8.02^{b}$ & 61.58 & 91.78 & 38.51 & 8.22 & $49.33 \pm 14.71^{b}$ \\
\hline & 3 Portions & $73.62 \pm 9.68^{c}$ & 70.85 & 96.30 & 21.84 & 3.70 & $62.17 \pm 8.06^{\mathrm{c}}$ \\
\hline
\end{tabular}

* Sum of content in the biomass and in the medium

Different letters indicate significant differences between means $(n=3, p<0.05)$ based on Duncan's test 
divided into three portions ( 85.73 and $81.66 \%$, respectively) (Fig. 4). With hydroquinone delivered in higher doses (above $200 \mathrm{mg} / \mathrm{l}$ ), the maximum efficiency did not exceed $66.50 \%$.

\section{Discussion}

In the agitated cultures of both plants, the increases in dry biomass during the 4-week culture cycles on the tested variants of the MS medium were similar, about threefold. These increases were comparable with those in the agitated cultures of A. melanocarpa maintained on the same variants of the MS medium (unpublished). In the agitated shoot cultures of Hypericum perforatum (cvs. Elixir, Helos and Topas) (Kwiecień et al. 2015, 2018), Ruta graveolens (Ekiert and Czygan 2005) and Schisandra chinensis (Szopa et al. 2016) maintained by us previously, we had obtained slightly higher (by several times, from four to ninefold) increases in dry biomass.

The estimated phenolic acids were accumulated in the biomass; no compounds were detected in the media. The same phenomenon was observed in agitated cultures of other plant species, e.g., for schisandra lignans in $S$. chinensis (Szopa et al. 2016), and also for furanocoumarins in $R$. graveolens and $R$. graveolens ssp. divaricata (Ekiert and Czygan 2005), and for phenolic acids and flavonoids in H. perforatum (cvs. Elixir, Helos and Topas) (Kwiecień et al. 2015, 2018).

The qualitative composition of the free phenolic acids estimated in extracts from the biomass cultured in vitro was the same as in the case of extracts from the fruits of soil-grown plants (Table 1). There were, however, marked quantitative differences. In A. arbutifolia shoots cultured in vitro, the main accumulated metabolites were chlorogenic acid (122.83-145.44 mg/100 g DW) and rosmarinic acid (78.57-147.98 mg/100 g DW). The maximum amounts of these metabolites were about 9 times (8.94 and 9.11-fold) higher than in the fruit (16.27 and $16.24 \mathrm{mg} / 100 \mathrm{~g} \mathrm{DW}$, respectively). Also, the amounts of 3,4-dihydroxyphenylacetic acid accumulated in vitro were 2.76 times higher than in fruit extracts. These three metabolites (chlorogenic, neochlorogenic and 3,4-dihydroxyphenylacetic acids) have very valuable biological properties, such as antioxidant, anti-inflammatory, immunostimulating, antiaggregatory and anticancer activities (Petersen and Simmonds 2003; Kampa et al. 2004; Thurow 2012; Ekiert et al. 2013a; Döring and Petersen 2014). The obtaining of significant amounts of them in agitated cultures should be regarded as a success. By contrast, the amounts of neochlorogenic acid were about 3.29 times higher in extracts from the fruit in comparison with in vitro cultured biomass (Szopa et al. 2018).
The total amounts of phenolic acids obtained in vitro were 2.21-2.47 times higher than in extracts from A. arbutifolia fruits (Szopa et al. 2018).

It is also important to compare the current results with those obtained previously in stationary cultures of A. arbutifolia. What draws the attention are the markedly higher amounts of chlorogenic acid, rosmarinic acid and 3,4-dihydroxyphenylacetic acid in agitated cultures, but a slightly lower neochlorogenic acid content. The total amounts of phenolic acids in the agitated cultures were as much as 2.73-5.42 times higher than in the stationary cultures conducted on media of identical composition of PGRs (Szopa et al. 2018).

Also in the case of A. $\times$ prunifolia, the qualitative composition of the phenolic acids estimated in vitro was identical to that in extracts from the fruits of soil-grown plants (Table 2). The main metabolites in vitro were chlorogenic acid, rosmarinic acid and 3,4-dihydroxyphenylacetic acid (142.97-260.34, 97.80-225.71 and 66.80-98.65 mg/100 g DW, respectively). The dominant compounds in fruit extracts were: chlorogenic acid and neochlorogenic acid (273.45 and $212.56 \mathrm{mg} / 100 \mathrm{~g}$ DW, respectively). The 3,4-dihydroxyphenylacetic acid and rosmarinic acid contents were very low (4.29 and $9.15 \mathrm{mg} / 100 \mathrm{~g} \mathrm{DW}$, respectively) (Szopa et al. 2017).

The maximum amounts of chlorogenic acid in vitro matched the amounts found in extracts from the fruit. The maximum amounts of neochlorogenic acid were about three times lower, but the amounts of rosmarinic acid and 3,4-dihydroxyphenylacetic acid obtained in vitro were several times higher (Table 2). The maximum total amount of phenolic acids obtained in vitro, approx. $660 \mathrm{mg} / 100 \mathrm{~g} \mathrm{DW}$, was only 1.22 times higher than in extracts from the fruit of A. × prunifolia (Szopa et al. 2018). A valuable result obtained in vitro was the very high amount of rosmarinic acid (approx. $226 \mathrm{mg} / 100 \mathrm{~g} \mathrm{DW}$ ). The comparison with the results obtained earlier in stationary cultures indicates that agitated cultures are a particularly rich source of chlorogenic acid and 3,4-dihydroxyphenylacetic acid. In the stationary cultures of A. × prunifolia, the presence of the 3,4-dihydroxyphenylacetic acid had not been confirmed at all (Szopa et al. 2018).

The total amounts of phenolic acids obtained in agitated cultures of Aronias were higher than in agitated cultures of $H$. perforatum (cvs. Elixir, Helos and Topas), cultured on MS media with the same composition of PGRs (Kwiecień et al. 2015).

The estimated flavonoids, like phenolic acids, were accumulated in the biomass; no compounds were detected in the media. In agitated cultures of $A$. arbutifolia, the analyses demonstrated the presence of three flavonoid compounds: the flavonoid aglycone-quercetin, and two of its glycosides-quercitrin and rutoside. The main metabolite was quercitrin. The maximum total amount of this group of 
compounds, equal to $65.26 \mathrm{mg} / 100 \mathrm{~g} \mathrm{DW}$, was about twice as high as in the fruits of soil-grown plants, in which only the presence of quercetin was confirmed $(31.83 \mathrm{mg} / 100 \mathrm{~g}$ DW) (Szopa et al. 2018) (Table 3).

Also in agitated cultures of $A . \times$ prunifolia, the LCDAD analysis confirmed the presence of the flavonoid aglycone-quercetin, and its two glycosides: quercitrin and rutoside. The quantitatively dominant compound was also quercitrin. The maximum amount of flavonoid compounds was about 1.8 times higher than in the fruit. In fruit extracts, only the presence of quercetin $(44.26 \mathrm{mg} / 100 \mathrm{~g} \mathrm{DW})$ was confirmed. It is interesting that the main metabolite in both Aronia cultures in vitro was quercitrin-a compound with many valuable biological activities (Camuesco et al. 2004; Wagner et al. 2006) (Table 4).

The study also proved the influence of the different concentrations of PGRs, BA and NAA, on the accumulation of both phenolic acids and flavonoids. The amounts of individual phenolic acids in A. arbutifolia cultures increased between 1.12 and 2.40 times. Also, the total content increased up to 1.12-fold depending on the variant of the MS medium. The best 'production' medium was the MS variant containing $2 \mathrm{mg} / \mathrm{l} \mathrm{BA}$ and $1 \mathrm{mg} / \mathrm{l} \mathrm{NAA}$. In the case of flavonoids, their individual amounts varied from 1.13 to 3.16fold, and the total content increased up to 1.13 -fold. The maximum flavonoid contents on all the tested MS medium variants were similar, with the highest amounts confirmed on the MS medium containing $0.5 \mathrm{mg} / \mathrm{l} \mathrm{BA}$ and $2.0 \mathrm{mg} / \mathrm{l}$ $\mathrm{NAA}$, and $3.0 \mathrm{mg} / \mathrm{l} \mathrm{BA}$ and $1.0 \mathrm{mg} / \mathrm{l} \mathrm{NAA}$.

In the case of $A . \times$ prunifolia cultures, the amounts of individual phenolic acids varied from 1.48- to 2.64-fold, and the total content increased up to 1.22 -fold. The best 'production' medium proved to be the MS variant containing $3 \mathrm{mg} / \mathrm{l} \mathrm{BA}$ and $1 \mathrm{mg} / \mathrm{l} \mathrm{NAA}$. The same variant favoured the accumulation of flavonoids, and could be a 'universal' production medium.

The influence of PGRs on the production of secondary metabolites in in vitro cultivated biomass of different plant species had been proven before, e.g. for anthocyanins in Vitis vinifera ( $\mathrm{Qu}$ et al. 2006), alkaloids in Lycopodiella inundata (Bienaimé et al. 2015), isoflavones in Psoralea cordifolia (Shinde et al. 2009) and phenolic compounds in Stevia rebaudiana (Radić et al. 2016).

Based on the results obtained, it is notable that the cytokinin/auxin ratio had an influence on the accumulation of phenolic compounds in the studied Aronia cultures in vitro (Tables 3,4). The predominance of cytokinin was conducive to the endogenous accumulation of phenolic acids and flavonoids (Karuppusamy 2009; Murthy et al. 2014). Some reports have confirmed the stimulating effect of exogenous benzyladenine (BA) supplementation on the production of saponins in Panax ginseng hairy root cultures (Murthy et al. 2014) or withanolide A in suspension cultures of Withania somnifera (Nagella and Murthy 2010). The exogenous supplementation with different cytokinin/auxin ratios was studied e.g. in hairy root cultures of Cichorium intybus (Bais et al. 2001). The exogenously added PGRs had an effect on biomass growth and coumarin biosynthesis, wherein transformed roots of $C$. intybus treated with increasing auxin-to-cytokinin ratios lost their capacity for coumarin biosynthesis.

In summary, the results of the research on endogenous accumulation of metabolites demonstrated a high biosynthetic potential of the cells of A. arbutifolia and A. $\times$ prunifolia shoots cultured in vitro in agitated systems. Agitated cultures of $A . \times$ prunifolia proved to be a rich source of both phenolic acids and flavonoids. The resulting total amounts of these two groups of compounds are, respectively, 1.66- and 1.28-fold higher than in A. arbutifolia cultures. As a hybrid, A. $\times$ prunifolia has a greater biosynthetic potential, which we had proven earlier in our phytochemical studies, and have now demonstrated in a biotechnological study (Szopa et al. 2017, 2018). Moreover, the phenomenon of higher secondary metabolite production in polyploid hybrids is a well-known fact (Lavania 2005).

As part of the ongoing research, we have proven the ability of cells of A. arbutifolia and A. $\times$ prunifolia to perform bioconversion of exogenously administered hydroquinone into its $\beta$-D-glucoside, arbutin. Glucosylation reactions are typical of cells in plant in vitro cultures (Tabata et al. 1988). In the majority of cases, the efficiency of the biotransformation process depends on the studied in vitro plant species as well as on the applied scheme of administering compounds-single or multiple doses, and time of supplementation (Carew and Bainbridge 1976; Ishihara et al. 2003). There are many reports on successful possibilities of performing the glucosylation process by different plant tissue cultures. They are capable of glucosylating substrates such as simple phenolic compounds, steroids, terpenoids, cardenolides, as well as hydroquinone into its $\beta$-D-glucosidearbutin (Tabata et al. 1988). The problem is the efficiency of the biotransformation run. The average amounts of arbutin obtained by bioconversion of different precursors fluctuate within a wide range, from 0.9 to $7.4 \mathrm{~g} / 100 \mathrm{~g}$ DW (Dušková et al. 1999). Only in a few cases that was possible to obtain satisfactory optimization of this process in in vitro cultivated biomass. In Datura innoxia suspension cultures, the efficiency of the biotransformation process reached a maximum of $45 \%$, after supplementing the culture with $10 \mathrm{mM}$ of hydroquinone and incubating it for $24 \mathrm{~h}$ (Suzuki et al. 1987). In suspension cultures of Catharanthus roseus (Inomata et al. 1991) and Rauwolfia serpentina (Lutterbach and Stöckigt 1992), a continuous supply of hydroquinone was provided. The maximum yields of arbutin $-9.2 \mathrm{~g} / 1$ (98\% process efficiency) and $18 \mathrm{~g} / \mathrm{l}$ ( $83 \%$ process efficiency), were obtained after exogenously supplying $364 \mathrm{mM}$ and $242 \mathrm{mM}$ of hydroquinone, respectively, $24 \mathrm{~h}$ before harvesting the 
biomass. The maximum total amounts of the product, in $A$. arbutifolia and $A . \times$ prunifolia in vitro cultures equal to 8.35 and $7.36 \mathrm{~g} / 100 \mathrm{~g} \mathrm{DW}$ respectively, are comparable with those that we had obtained by an analogous optimization procedure in in vitro cultures of $A$. melanocarpa, Hypericum perforatum, Ruta graveolens and S. chinensis (max. 8.2, 7.2, 7.8 and $5.08 \mathrm{~g} / 100 \mathrm{~g} \mathrm{DW}$, respectively) (Piekoszewska et al. 2010; Kwiecień et al. 2013; Szopa et al. 2018). Almost all of the amounts obtained after the optimization process were higher than those required by the European Pharmacopoeia 9th ed. for Uvae ursi folium (7.0 g/100 g DW) (European Directorate for the Quality of Medicines 2017) and are interesting from a practical point of view.

As a whole, the study results demonstrate for the first time the high biosynthetic potential of cells from agitated cultures of both plants. The obtained results are very interesting and demonstrated a high biosynthetic potential of agitated cultures of both plants. We propose agitated cultures of A. arbutifolia and A. $\times$ prunifolia as a rich source of chlorogenic acid, rosmarinic acid and quercitrin.

Author contributions AS and PK carried out the experiments, compiled the data, performed the chemical and statistical analyses. HE wrote the manuscript with support from AS.

\section{Compliance with ethical standards}

Conflict of interest The authors declare that there are no conflicts of interests. All the authors read and approved the manuscript in its final form.

Open Access This article is distributed under the terms of the Creative Commons Attribution 4.0 International License (http://creativeco mmons.org/licenses/by/4.0/), which permits unrestricted use, distribution, and reproduction in any medium, provided you give appropriate credit to the original author(s) and the source, provide a link to the Creative Commons license, and indicate if changes were made.

\section{References}

Arts ICW, Hollman PCH (2005) Polyphenols and disease risk in epidemiologic studies. Am J Clin Nutr 81:317S-325S

Bais HP, Sudha G, George J, Ravishankar GA (2001) Influence of exogenous hormones on growth and secondary metabolite production in hairy root cultures of Cichorium intybus L. CV. Lucknow local. In Vitro Cell Dev Biol Plant 37:293-299. https://doi. org/10.1007/s11627-001-0052-8

Bienaimé C, Melin A, Bensaddek L et al (2015) Effects of plant growth regulators on cell growth and alkaloids production by cell cultures of Lycopodiella inundata. Plant Cell Tissue Organ Cult 123:523533. https://doi.org/10.1007/s11240-015-0856-6

Brand MH, Cullina WG (1992) Micropropagation of red and black chokeberry (Aronia spp.). Hortic Sci 27:81-81

Camuesco D, Comalada M, Rodríguez-Cabezas ME et al (2004) The intestinal anti-inflammatory effect of quercitrin is associated with an inhibition in iNOS expression. Br J Pharmacol 143:908-918. https://doi.org/10.1038/sj.bjp.0705941
Carew DP, Bainbridge T (1976) Biotransformations with plant tissue cultures. Lloydia 39:147-149

D'Andrea G (2015) Quercetin: a flavonol with multifaceted therapeutic applications? Fitoterapia 106:256-271. https://doi.org/10.1016/j. fitote.2015.09.018

Döring AS, Petersen M (2014) Production of caffeic, chlorogenic and rosmarinic acids in plants and suspension cultures of Glechoma hederacea. Phytochem Lett 10:cxi-cxvii. https://doi. org/10.1016/j.phytol.2014.05.012

Dušková J, Dušek J, Jahodár L (1999) Zur Biotransformation von Hydrochinon zu Arbutin in den in vitro-Kulturen. Herba Pol 45:23-26

Ekiert H, Czygan F-C (2005) Accumulation of biologically active furanocoumarins in agitated cultures of Ruta graveolens L. and Ruta graveolens ssp. divaricata (Tenore) Gams. Pharmazie 60:623-626

Ekiert H, Kwiecień I, Szopa A (2013a) Rosmarinic acid production in plant in vitro cultures. Pol J Cosmetol 16:49-58

Ekiert H, Kwiecień I, Szopa A, Muszyńska B (2013b) Possibilities of arbutin production using plant biotechnology methods. Pol J Cosmetol 15:151-162

Ellnain-Wojtaszek M, Zgorka G (1999) High-performance liquid chromatography and thin-layer chromatography of phenolic acids from Ginkgo biloba L. leaves collected within vegetative period. J Liq Chromatogr Relat Technol 22:1457-1471. https:// doi.org/10.1081/JLC-100101744

European Directorate for the Quality of Medicines (2017) Schisandra fruit. European Pharmacopoeia 9.0. European Directorate for the Quality of Medicines, Strasburg, p 1514

Giri L, Dhyani P, Rawat S et al (2012) In vitro production of phenolic compounds and antioxidant activity in callus suspension cultures of Habenaria edgeworthii: A rare Himalayan medicinal orchid. Ind Crops Prod 39:1-6. https://doi.org/10.1016/j.inder op.2012.01.024

Hussain MS, Fareed S, Ansari S et al (2012) Current approaches toward production of secondary plant metabolites. J Pharm Bioallied Sci 4:10-20. https://doi.org/10.4103/0975-7406.92725

Inomata S, Yokoyama M, Seto S, Yanagi M (1991) High-level production of arbutin from hydroquinone in suspension cultures of Catharanthus roseus plant cells. Appl Microbiol Biotechnol https://doi.org/10.1007/BF00208148

Ishihara K, Hamada H, Hirata T, Nakajima N (2003) Biotransformation using plant cultured cells. J Mol Catal B Enzym 23:145170. https://doi.org/10.1016/S1381-1177(03)00080-8

Kakkar S, Bais S (2014) A review on protocatechuic acid and its pharmacological potential. ISRN Pharmacol. https://doi. org/10.1155/2014/952943

Kampa M, Alexaki V-I, Notas G et al (2004) Antiproliferative and apoptotic effects of selective phenolic acids on T47D human breast cancer cells: potential mechanisms of action. Breast Cancer Res 6:63-74. https://doi.org/10.1186/bcr752

Karuppusamy S (2009) A review on trends in production of secondary metabolites from higher plants by in vitro tissue, organ and cell cultures. J Med Plants Res 3:1222-1239

Krolicka A, Szpitter A, Maciag M et al (2008) Antibacterial and antioxidant activity of the secondary metabolites from in vitro cultures of Drosera aliciae. Biotechnol Appl Biochem 53:175184. https://doi.org/10.1042/BA20080088

Kulling SE, Rawel HM (2008) Chokeberry (Aronia melanocarpa): a review on the characteristic components and potential health effects. Planta Med 74:1625-1634. https://doi. org/10.1055/s-0028-1088306

Kwiecień I, Szopa A, Madej K, Ekiert H (2013) Arbutin production via biotransformation of hydroquinone in in vitro cultures of Aronia melanocarpa (Michx.) Elliott. Acta Biochim Pol $60: 865-870$ 
Kwiecień I, Szydłowska A, Kawka B et al (2015) Accumulation of biologically active phenolic acids in agitated shoot cultures of three Hypericum perforatum cultivars: "Elixir", "Helos" and “Topas”. Plant Cell Tissue Organ Cult 123:273-281. https:// doi.org/10.1007/s11240-015-0830-3

Kwiecień I, Smolin J, Beerhues L, Ekiert H (2018) The impact of media composition on production of flavonoids in agitated shoot cultures of the three Hypericum perforatum cultivars "Elixir", "Helos" and "Topas". In Vitro Cell Dev Biol Plant 54:332-340. https://doi.org/10.1007/s11627-018-9900-7

Lavania UC (2005) Genomic and ploidy manipulation for enhanced production of phyto-pharmaceuticals. Plant Genet Resour 3:170-177. https://doi.org/10.1079/PGR200576

Lutterbach R, Stöckigt J (1992) High-yield formation of arbutin from hydroquinone by cell-suspension cultures of Rauwolfia serpentina. Helv Chim Acta 75:2009-2011. https://doi.org/10.1002/ hlca. 19920750625

Matkowski A (2008) Plant in vitro culture for the production of antioxidants: a review. Biotechnol Adv 26:548-560. https://doi. org/10.1016/j.biotechadv.2008.07.001

Meng S, Cao J, Feng Q et al (2013) Roles of chlorogenic acid on regulating glucose and lipids metabolism: a review. Evid Based Complement Altern Med. https://doi.org/10.1155/2013/801457

Migas P, Krauze-Baranowska M (2015) The significance of arbutin and its derivatives in therapy and cosmetics. Phytochem Lett 13:35-40. https://doi.org/10.1016/j.phytol.2015.05.015

Murashige T, Skoog F (1962) A revised medium for rapid growth and bioassays with tobacco tissue cultures. Physiol Plant 15:473-479

Murthy HN, Lee E-J, Paek K-Y (2014) Production of secondary metabolites from cell and organ cultures: strategies and approaches for biomass improvement and metabolite accumulation. Plant Cell Tissue Organ Cult 118:1-16. https://doi.org/10.1007/s1124 0-014-0467-7

Nagella P, Murthy HN (2010) Establishment of cell suspension cultures of Withania somnifera for the production of withanolide A. Bioresour Technol 101:6735-6739. https://doi.org/10.1016/j.biort ech.2010.03.078

Pasetto S, Pardi V, Murata RM (2014) Anti-HIV-1 activity of flavonoid myricetin on HIV-1 infection in a dual-chamber in vitro model. PLoS ONE 9:e115323. https://doi.org/10.1371/journ al.pone. 0115323

Petersen M, Simmonds MSJ (2003) Rosmarinic acid. Phytochemistry 62:121-125

Piazzon A, Vrhovsek U, Masuero D et al (2012) Antioxidant activity of phenolic acids and their metabolites: synthesis and antioxidant properties of the sulfate derivatives of ferulic and caffeic acids and of the acyl glucuronide of ferulic acid. J Agric Food Chem 60:12312-12323. https://doi.org/10.1021/jf304076z

Piekoszewska A, Ekiert H, Zubek S (2010) Arbutin production in Ruta graveolens and Hypericum perforatum $\mathrm{L}$. in vitro cultures. Acta Physiol Plant 32:223-229

Procházková D, Boušová I, Wilhelmová N (2011) Antioxidant and prooxidant properties of flavonoids. Fitoterapia 82:513-523. https ://doi.org/10.1016/j.fitote.2011.01.018
Qu J-G, Yu X-J, Zhang W, Jin M-F (2006) Significant improved anthocyanins biosynthesis in suspension cultures of Vitis vinifera by process intensification. Sheng Wu Gong Cheng Xue Bao 22:299-305

Radić S, Vujčić V, Glogoški M, Radić-Stojković M (2016) Influence of $\mathrm{pH}$ and plant growth regulators on secondary metabolite production and antioxidant activity of Stevia rebaudiana (Bert). Period Biol. https://doi.org/10.18054/PB.V118I1.3420

Shinde AN, Malpathak N, Fulzele DP (2009) Enhanced production of phytoestrogenic isoflavones from hairy root cultures of Psoralea corylifolia L. using elicitation and precursor feeding. Biotechnol Bioprocess Eng 14:288-294. https://doi.org/10.1007/s1225 7-008-0238-6

Štambergová A, Supčiková M, Leifertová I (1985) Hodnoceni fenolických lítek v Arctostaphylos uva-ursi. IV. Stanoveni arbutinu, metylarbutinu a hydrochinonu v listech metodou HPLC. Ceskoslov Farm 34:179-183

Sułkowska-Ziaja K, Maślanka A, Szewczyk A, Muszyńska B (2017) Physiologically active compounds in four species of Phellinus. Nat Prod Commun 12:363-366

Suzuki T, Yoshioka T, Tabata M, Fujita Y (1987) Potential of Datura innoxia cell suspension cultures for glucosylating hydroquinone. Plant Cell Rep 6:275-278. https://doi.org/10.1007/BF00271997

Szopa A, Kokotkiewicz A, Marzec-Wróblewska U et al (2016) Accumulation of dibenzocyclooctadiene lignans in agar cultures and in stationary and agitated liquid cultures of Schisandra chinensis (Turcz.) Baill. Appl Microbiol Biotechnol 100:3965-3977. https ://doi.org/10.1007/s00253-015-7230-9

Szopa A, Kokotkiewicz A, Kubica P et al (2017) Comparative analysis of different groups of phenolic compounds in fruit and leaf extracts of Aronia sp.: A. melanocarpa, A. arbutifolia. and $A . \times$ prunifolia and their antioxidant activities. Eur Food Res Technol 243:1645-1657. https://doi.org/10.1007/s0021 7-017-2872-8

Szopa A, Kubica P, Snoch A, Ekiert H (2018) High production of bioactive depsides in shoot and callus cultures of Aronia arbutifolia and Aronia $\times$ prunifolia. Acta Physiol Plant 40:48. https://doi. org/10.1007/s11738-018-2623-x

Tabata M, Umetani Y, Ooya M, Tanaka S (1988) Glucosylation of phenolic compounds by plant cell cultures. Phytochemistry 27:809813. https://doi.org/10.1016/0031-9422(88)84097-4

Taheri R, Connolly BA, Brand MH, Bolling BW (2013) Underutilized chokeberry (Aronia melanocarpa, Aronia arbutifolia. Aronia prunifolia) accessions are rich sources of anthocyanins, flavonoids, hydroxycinnamic acids, and proanthocyanidins. J Agric Food Chem 61:8581-8588. https://doi.org/10.1021/jf402449q

Thurow T (2012) Effect of chlorogenic acid and neochlorogenic acid on human colon cancer cells. Food Sci Undergraduate Honors Theses Paper 2. http://scholarworks.uark.edu

Wagner C, Fachinetto R, Dalla Corte CL et al (2006) Quercitrin, a glycoside form of quercetin, prevents lipid peroxidation in vitro. Brain Res 1107:192-198. https://doi.org/10.1016/j.brain res.2006.05.084 